\title{
Studies on correlation and heritability estimates in upland cotton (Gossypium hirsutum L.) genotypes under the agro- climatic conditions of Tandojam, Sindh, Pakistan
}

\author{
Zeeshan Majeed Kumbhar ${ }^{1}$, Wajid Ali Jatoi ${ }^{1}$, Jay Kumar Sootaher ${ }^{1 *}$, \\ Muhammad Ishaque Baloch ${ }^{2}$, Adil Ali Gadahi ${ }^{1}$, Kirshan Kumar \\ Menghwar ${ }^{1}$, Muhammad Saleem Chang ${ }^{3}$ and Mitho Kachi ${ }^{1}$ \\ 1. Department of Plant Breeding and Genetics, Sindh Agriculture University, Tandojam, Sindh-Pakistan \\ 2. Mango Research Institute, Mirpurkhas, Sindh-Pakistan \\ 3. Department of Agronomy, Subcampus Umerkot, Sindh Agriculture University, Tandojam, Sindh-Pakistan \\ *Corresponding author's email: jaykumar3030@gmail.com \\ Citation \\ Zeeshan Majeed Kumbhar, Wajid Ali Jatoi, Jay Kumar Sootaher, Muhammad Ishaque Baloch, Adil Ali Gadahi, \\ Kirshan Kumar Menghwar, Muhammad Saleem Chang and Mitho Kachi. Studies on correlation and heritability \\ estimates in upland cotton (Gossypium hirsutum L.) genotypes under the agro-climatic conditions of Tandojam, \\ Sindh, Pakistan. Pure and Applied Biology. Vol. 9, Issue 4, pp2272-2278. \\ http://dx.doi.org/10.19045/bspab.2020.90241
}

Received: $12 / 03 / 2020 \quad$ Revised: $16 / 06 / 2020$

Accepted: 24/06/2020

Online First: 08/07/2020

\section{Abstract}

The experiment was conducted for the evaluation of association among morphological attributes in upland cotton genotypes at Cotton Section, Agriculture Research Institute, Tandojam during the year 2017 in RCBD with four replications. The mean squares articulated a good magnitude of variation in the genotypes for all characteristics. Mehran produced shorter plants $(111.00 \mathrm{~cm})$, higher ginning outturn $(40.25 \%)$ and staple length $(28.50 \mathrm{~mm})$. Sadori displayed maximum sympodia (30.75). FH-901 showed higher bolls setting plant1 (56.50) and highest seed cotton yield plant-1 (175.32 g). Koonj produced bigger bolls ( $3.37 \mathrm{~g})$ and highest micronaire value $(4.70 \mu \mathrm{g} / \mathrm{inch})$. Sindh-1 recorded higher lint index $(5.50 \mathrm{~g})$. There was observed positive as well as significant interrelationship of seed cotton yield with the most important traits such as bolls plant1 and boll weight. The heritability values were observed in two ranges in which all the attributes articulated high heritabilities $(90.74 \%, 97.63 \%, 91.16 \%, 92.30 \%, 92.98 \%, 83.38 \%, 74.69 \%, 69.26 \%$ and $62.50 \%)$ except lint index which manifested moderated heritability (46.77\%). It was finalized that these genotypes performed very well and must be utilized in hybridization programme for the improvement of yield and fiber traits in new cotton genotypes.

Keywords: Correlation; Heritability; Upland cotton; Genotypes; Agro-climatic conditions

\section{Introduction}

Upland cotton has been a major cash crop for the production thread, clothes and oil in the glove. It is tetraploid with the chromosome number of $2 n=4 x=52$. Nowadays, two new world cotton species are dominant over the glove [1] in which $90 \%$ fiber is supplied by this cotton (Gossypium hirsutum L.), although 3\% fiber is produced by Egyptian cotton (Gossypium barbadense L.). The crop is grown in more than 80 countries all over the globe [2].
It was estimated that in Pakistan, the crop was grown on 11,935 million hectares and seed cotton production was 13.983 million bales with average seed cotton yield of $752 \mathrm{~kg} \mathrm{ha}^{-1}$. Need for cotton is day by day increasing owing to the increase in the growth rate of population [3].

Before initiating any cotton improvement program, information about the genetic potential of various genotypes and degree of association of yield with various morphological 
and yield traits is important for the breeders to handle a problem wisely and enhance the yield to a sufficient extent $[4,5]$.

The information about the simple correlation of agronomic, morphological and quality characters with yield is helpful in identification of the yield component. The kinds of correlation play a huge role in the calculation of attributes in which positive correlation indicates that an increase in one character will bring a simultaneous increase in the other associated character. Whereas, negative correlation suggests that an increase in one character causes a decrease in the other associated character. So, the positive correlation between two desirable characters and negative correlation between a desirable and undesirable character is important [6].

Heritability is always passed on from parents to offspring and play an important role in the field of plant breeding and genetics due to the fact that it informs us how much a phenotypic attribute is contributed by genes in a population [7]. Similarly, association of heritability with selection response helps in understanding the mode of inheritance of various quantitative traits [8].

For that reason, the main motive of this research work is to determine correlation of characters of upland cotton genotypes among the various agro-morphological to identify the traits that may be useful in selection.

\section{Materials and methods}

The field trail was conducted to observe association and heritability in ten upland cotton genotypes in a RCBD entailing three replications in an experimental field of Cotton Section, Agriculture Research Institute, Tandojam during 2017-18. The genotypes of upland cotton were CRIS-134, CRIS-342, CRIS-121, Sadori, Chandi, Sindh-1, Mehran, Bakhtawar, Koonj and FH-901.

Following traits were investigated with a brief methodology.

\section{Plant height (cm)}

Plant height was measured in centimetres from ground level to the tip of plant.

\section{Sympodial branches plant ${ }^{-1}$}

The sympodial branches or fruiting branches were counted at the time of picking.

\section{Bolls plant ${ }^{-1}$}

Fully opened bolls were picked in two pickings from each tagged plant. The total numbers of picked bolls were counted as number of productive bolls plant ${ }^{-1}$.

\section{Boll weight (g)}

Average bolls weight from five picked bolls plant $^{-1}$ was calculated on digital balance in laboratory.

\section{Seed cotton yield plant ${ }^{-1}(\mathrm{~g})$}

Separate pickings of all tagged plants were done and weighed on a digital balance in grams for recoding seed cotton plant ${ }^{-1}$.

\section{Ginning out turn (\%)}

The clean and dry seed cotton samples were weighed before ginning in grams and then ginned with an electric saw gin machine. The lint percentage was calculated by using the following formula:

\section{GOT \% = _ Weight of lint $\quad$ × 100 \\ Weight of Seed cotton sample}

Seed index (100 seed weight, $g$ )

One hundred seeds were randomly counted and weighed on digital balance in grams for recording seed index.

\section{Lint index (g)}

The lint of 100-seeds was weighted on digital balance for recording lint index in grams.

\section{Staple length $(\mathbf{m m})$}

The fibre or staple length was measured at $2.5 \%$ span length by using the fibro graph, ModelHVI-900.

\section{Micronaire value $(\mu \mathrm{g} / \mathrm{inch})$}

The fibre fineness was measured by using the fibro graph, Model-HVI-900.

\section{Statistical analysis}

The data for ANOVA were brought under the methods developed by [9], LSD was tested according to [10], whereas correlation coefficient was determined by adopting the procedure of [11] and heritability was estimated according to [12].

\section{Results and discussion}

Cotton breeders are trying to combine the desirable genes as well as novel combinations of alleles in cotton plants. That goals of breeders are to develop crop varieties that produce unique and superior traits. In cotton, varieties to produce more seed cotton yield and good fiber quality are highly preferable. Some researchers reported that the seed cotton yield and fiber quality traits are influenced by the environmental cues a lot due to polygenes. Thus, conception of interrelationship among attributes is more important for the success of a plant breeder.

\section{Analysis of variance}

The achieved results revealed that varieties differed highly significantly and significantly at the probability level of 0.01 and 0.05 for all of 
the characters (Table $1 \&$ 2). This manifested that a large amount of a considerable genetic diversity was found in genotypes as well as characteristics. Our outcomes are in paradox with [13] except fiber fitness. Furthermore, [14] exposed the same variations in these traits. One the other hand, such similar had also been told by [15] excluding seed index.

Table 1. Mean squares for different morphological traits of upland cotton

\begin{tabular}{|c|c|c|c|c|c|c|}
\hline SOV & D. F. & $\begin{array}{c}\text { Plant height } \\
(\mathrm{cm})\end{array}$ & $\begin{array}{c}\text { Sympodial } \\
\text { branches plant }^{-1}\end{array}$ & $\begin{array}{c}\text { Bolls } \\
\text { plant }^{-1}\end{array}$ & $\begin{array}{c}\text { Boll } \\
\text { weight (g) }\end{array}$ & $\begin{array}{c}\text { Seed cotton } \\
\text { yield plant }{ }^{-1}(g)\end{array}$ \\
\hline Replications & 3 & 1.89 & 2.35 & 13.36 & 0.052 & 413.33 \\
\hline Varieties & 9 & $567.35 * *$ & $38.61 * *$ & $108.72 * *$ & $0.138 * *$ & $881.85 * *$ \\
\hline Error & 27 & 2.04 & 1.22 & 0.40 & 0.018 & 53.18 \\
\hline Total & 39 & - & - & - & - & - \\
\hline
\end{tabular}

Table 2. Mean squares for different morphological traits of upland cotton

\begin{tabular}{|c|c|c|c|c|c|c|}
\hline SOV & D. F. & $\begin{array}{c}\text { Ginning } \\
\text { outturn }(\%)\end{array}$ & $\begin{array}{c}\text { Seed } \\
\text { index }(\mathbf{g})\end{array}$ & $\begin{array}{c}\text { Lint index } \\
(\mathbf{g})\end{array}$ & $\begin{array}{c}\text { Staple length } \\
(\mathbf{m m})\end{array}$ & $\begin{array}{c}\text { Micronaire value } \\
(\boldsymbol{\mu g} / \mathbf{i n c h})\end{array}$ \\
\hline Replications & 3 & 6.20 & 0.27 & 0.62 & 8.57 & 0.04 \\
\hline Varieties & 9 & $12.22^{* *}$ & $5.37^{* *}$ & $4.85^{* *}$ & $4.83^{* *}$ & $0.15^{*}$ \\
\hline Error & 27 & 1.68 & 1.15 & 2.31 & 1.27 & 0.05 \\
\hline Total & 39 & - & - & - & - & - \\
\hline
\end{tabular}

\section{Mean performance}

The mean performance (Table $3 \& 4$ ) of varieties showed that Sadori surpassed all the tested genotypes, produced maximum (145.00 $\mathrm{cm}$ ) plant height followed by CRIS-134 (141.25 $\mathrm{cm})$ and CRIS-121 $(139.50 \mathrm{~cm})$. While Mehran displayed the lowest plant height $(111.50 \mathrm{~cm})$. Cultivars with reduced plant height could be good for increasing seed cotton yield. In case of sympodial branches plant ${ }^{-1}$, the variety Sadori recoded maximum (30.75) sympodia, followed by CRIS-134 (29.50) and CRIS-342 (27.50), while the lowest sympodial branches plant $^{-1}$ was noted in Bakhtawar (20.75). FH-901 maximum (56.50) bolls plant $^{-1}$, followed by CRIS-134 (53.00) and CRIS-121 (51.00), however the minimum bolls plant ${ }^{-1}$ (39.50) were noticed in Koonj. Koonj produced higher boll weight (3.37 g) followed by Mehran (3.22 g) and Chandi (3.10 g), at the same time CRIS134 resulted in the lowest boll weight $(2.90 \mathrm{~g})$. FH-901 gave the highest (175.32 g) seed cotton yield plant ${ }^{-1}$ followed by CRIS-121 (155.70 g) and the lowest seed cotton yield plant ${ }^{-1}(128.75$ $\mathrm{g}$ and $128.35 \mathrm{~g}$ ) were expressed by the genotype Bakhtawar and CRIS-342 respectively.

Table 3. Mean performance of different upland cotton genotypes for yield and yield contributing attributes

\begin{tabular}{|c|c|c|c|c|c|}
\hline Genotypes & $\begin{array}{l}\text { Plant height } \\
\text { (cm) }\end{array}$ & $\begin{array}{c}\text { Sympodial } \\
\text { branches plant }^{-1}\end{array}$ & $\begin{array}{c}\text { Bolls } \\
\text { plant }^{-1}\end{array}$ & $\begin{array}{c}\text { Boll weight } \\
\text { (g) }\end{array}$ & $\begin{array}{l}\text { Seed cotton yield } \\
\text { plant }^{-1}(\mathrm{~g})\end{array}$ \\
\hline CRIS-134 & 141.25 & 29.50 & 53.00 & 2.90 & 153.78 \\
\hline CRIS-342 & 137.25 & 27.50 & 43.50 & 2.95 & 128.35 \\
\hline CRIS-121 & 139.50 & 27.50 & 51.00 & 3.05 & 155.70 \\
\hline Sadori & 145.00 & 30.75 & 48.50 & 3.00 & 145.45 \\
\hline Chandi & 129.25 & 25.50 & 43.50 & 3.10 & 134.95 \\
\hline Sindh-1 & 120.75 & 23.50 & 51.00 & 2.70 & 137.72 \\
\hline Mehran & 111.50 & 26.00 & 47.00 & 3.22 & 151.63 \\
\hline Bakhtawar & 116.00 & 20.75 & 44.00 & 2.92 & 128.75 \\
\hline Koonj & 124.25 & 24.75 & 39.50 & 3.37 & 133.32 \\
\hline FH-901 & 117.50 & 22.50 & 56.50 & 3.10 & 175.32 \\
\hline LSD at $1 \%$ & 3.45 & 0.98 & 1.38 & 0.12 & 6.78 \\
\hline
\end{tabular}

Batool et al. [16] also achieved the maximum seed cotton yield plant ${ }^{-1}$, sympodia plant $^{-1}$ and boll weight when he conducted the experiment. Mehran recorded the highest GOT $(40.25 \%)$ followed by CRIS-342 (39.50\%) and the lowest
GOT (35.50\%) was produced by the genotype Chandi. Sindh-1 exceeded in lint index of 5.50 $\mathrm{g}$ followed by Mehran (5.50 g) and the lowest lint index $(4.00 \mathrm{~g})$ was noted in genotype Bakhtawar and Koonj. Mehran gave longer 
(28.50 mm) staple length followed by FH-901 $(28.25 \mathrm{~mm})$ and shorter staple length $(25.25 \mathrm{~mm})$ was noted in genotype Koonj. Koonj gave more fiber fineness $(4.70 \mu \mathrm{g} / \mathrm{inch})$ followed by Bakhtawar (4.62 $\mu \mathrm{g} / \mathrm{inch})$ and less micronaire value (4.12 $\mu \mathrm{g} / \mathrm{inch})$ was observed in CRIS-342. On average, the similar findings were also showed by [17] for yield attributing traits and eventually increased the seed cotton yield.

Table 4. Mean performance of different upland cotton genotypes for yield and yield contributing attributes

\begin{tabular}{|c|c|c|c|c|c|}
\hline Genotypes & $\begin{array}{c}\text { Ginning } \\
\text { outturn }(\boldsymbol{\%})\end{array}$ & Seed index $(\mathbf{g})$ & $\begin{array}{c}\text { Lint index } \\
(\mathbf{g})\end{array}$ & $\begin{array}{c}\text { Staple length } \\
(\mathbf{m m})\end{array}$ & $\begin{array}{c}\text { Micronaire value } \\
(\boldsymbol{\mu g} / \text { inch })\end{array}$ \\
\hline CRIS-134 & 36.00 & 7.25 & 4.50 & 27.00 & 4.47 \\
\hline CRIS-342 & 39.50 & 6.25 & 4.50 & 26.50 & 4.12 \\
\hline CRIS-121 & 36.25 & 6.50 & 4.75 & 27.50 & 4.32 \\
\hline Sadori & 39.50 & 8.00 & 4.25 & 26.50 & 4.60 \\
\hline Chandi & 35.50 & 4.75 & 4.50 & 25.50 & 4.25 \\
\hline Sindh-1 & 36.50 & 7.00 & 5.50 & 25.75 & 4.17 \\
\hline Mehran & 40.25 & 7.50 & 5.00 & 28.50 & 4.50 \\
\hline Bakhtawar & 36.25 & 8.50 & 4.00 & 26.75 & 4.62 \\
\hline Koonj & 36.75 & 5.25 & 4.00 & 25.25 & 4.70 \\
\hline FH-901 & 38.50 & 7.00 & 4.25 & 28.25 & 4.47 \\
\hline LSD at 1\% & 1.39 & 0.42 & 0.16 & 0.28 & 0.11 \\
\hline
\end{tabular}

\section{Correlation (r)}

Correlation is very vital for plant breeding because it works an indirect selection criterion in the progress of yield and its controlling characteristics. The data are presented in (Table 5).

\section{Plant height}

It was discovered positive and significant linkages of plant height with sympodial branches plant ${ }^{-1}\left(\mathrm{r}=0.74^{* *}\right)$. This trait was also positively as well as negatively, but nonsignificantly connected with bolls plant ${ }^{-1}$ $\left(\mathrm{r}=0.07^{\mathrm{ns}}\right)$, GOT $\left(\mathrm{r}=0.05^{\mathrm{ns}}\right)$, seed index $\left(\mathrm{r}=0.07^{\mathrm{ns}}\right)$, lint index $\left(\mathrm{r}=0.02^{\mathrm{ns}}\right)$, staple length $\left(\mathrm{r}=0.16^{\mathrm{ns}}\right)$, micronaire value $\left(\mathrm{r}=0.12^{\mathrm{ns}}\right)$, bolls weight $\left(\mathrm{r}=-0.16^{\mathrm{ns}}\right)$ and seed cotton yield plant ${ }^{-1}$ $\left(\mathrm{r}=-0.03^{\mathrm{ns}}\right)$. Our findings were in agreement with [18] who also expressed positive and negative significance in these attributes.

\section{Sympodial branches plant ${ }^{-1}$}

The sympodial branches plant ${ }^{-1}$ was positively and negatively and significantly interrelated with bolls plant ${ }^{-1}\left(\mathrm{r}=0.33^{* *}\right)$ and boll weight $\left(\mathrm{r}=-0.40^{* *}\right)$. On the other hand, it was also nonsignificantly as well as positive associated with seed cotton yield $\left(\mathrm{r}=0.08^{\mathrm{ns}}\right)$, GOT $\left(\mathrm{r}=0.02^{\mathrm{ns}}\right)$, seed index $\left(\mathrm{r}=0.24^{\mathrm{ns}}\right)$ and staple length $\left(\mathrm{r}=0.001^{\mathrm{ns}}\right)$. Negative along with significant associations were found with lint index $\left(\mathrm{r}=0.07^{\mathrm{ns}}\right)$ and micronaire value $(\mathrm{r}=-$ $\left.0.05^{\text {ns }}\right) .[19]$ reported the same results and hence our results were in agreement with him.

\section{Bolls plant ${ }^{-1}$}

The bolls plant $^{-1}$ demonstrated positive, but significant and nonsignificant connections with seed cotton yield $(\mathrm{r}=0.79 * *)$ and staple length $\left(\mathrm{r}=0.43^{* *}\right)$, GOT $\left(\mathrm{r}=0.09^{\mathrm{ns}}\right)$, seed index $\left(\mathrm{r}=0.26^{\mathrm{ns}}\right)$ and lint index $\left(\mathrm{r}=0.08^{\mathrm{ns}}\right)$. Even the character appeared in negativity and significance with bolls weight $\left(\mathrm{r}=-0.27^{\mathrm{ns}}\right)$ and micronaire value $\left(\mathrm{r}=-0.03^{\mathrm{ns}}\right)$. [20] whose correlation results revealed highly significant and positive associations of boll numbers plant ${ }^{-}$ ${ }^{1}$ with seed cotton yield palnt ${ }^{-1}$.

\section{Bolls weight}

Positive with significant and nonsignificant associations of this trait were observed with seed cotton yield $\left(\mathrm{r}=0.35^{* *}\right)$, micronaire value $(\mathrm{r}=0.34 * *)$, GOT $\left(\mathrm{r}=0.20^{\mathrm{ns}}\right)$ and staple length $\left(\mathrm{r}=0.17^{\mathrm{ns}}\right)$, while significant and nonsignificant, but negative linkages were there with seed index $\left(\mathrm{r}=-0.34^{*}\right)$ and lint index $\left(\mathrm{r}=-0.21^{\mathrm{ns}}\right)$. The highly significant positive correlation was observed among bolls plant ${ }^{-1}$ and boll weight when [21] revealed that improvement may be effective through simple selection towards the seed cotton yield.

\section{Seed cotton yield plant ${ }^{-1}$}

The linkage of this character came into existence in the form of positivity and nonsignificance with GOT $\left(\mathrm{r}=0.24^{\mathrm{ns}}\right)$, seed index $\left(\mathrm{r}=0.04^{\mathrm{ns}}\right)$, staple length $\left(\mathrm{r}=0.54^{\mathrm{ns}}\right)$ and micronaire value $\left(\mathrm{r}=0.18^{\mathrm{ns}}\right)$. This trait was negative and non-significant associated with lint index $\left(r=-0.04^{\mathrm{ns}}\right)$. [22] Certified the association among traits and recommended that 
little variation in the genetic gain could bring a huge accomplishment in the life of a plant breeder.

\section{Ginning outturn}

This attribute was positively and nonsignificantly related with seed index $\left(\mathrm{r}=0.14^{\mathrm{ns}}\right)$, lint index $\left(\mathrm{r}=0.08^{\mathrm{ns}}\right)$, staple length $\left(\mathrm{r}=0.26^{\mathrm{ns}}\right)$ and micronaire value $\left(\mathrm{r}=0.02^{\mathrm{ns}}\right)$.

\section{Seed index}

Positive, but nonsignificant relationship of seed index was noticed with lint index $\left(\mathrm{r}=0.02^{\mathrm{ns}}\right)$, staple length $\left(\mathrm{r}=0.25^{\mathrm{ns}}\right)$ and micronaire value $\left(\mathrm{r}=0.08^{\mathrm{ns}}\right)$. These findings were the same as [23].

Table 5. Correlation of coefficients among various yield and yield contributing attributes in upland cotton genotypes

\begin{tabular}{|c|c|c|c|c|c|c|c|}
\hline $\begin{array}{c}\text { Character } \\
\text { Sympodial } \\
\text { branches plant }^{-1}\end{array}$ & $\begin{array}{c}\text { Plant } \\
\text { height }\end{array}$ & $\begin{array}{c}\text { Sympodial } \\
\text { branches plant }\end{array}$ & $\begin{array}{c}\text { Bolls } \\
\text { plant }^{-1}\end{array}$ & $\begin{array}{c}\text { Boll } \\
\text { weight }\end{array}$ & $\begin{array}{c}\text { Seed cotton } \\
\text { yield plant }\end{array}$ & $\begin{array}{c}\text { Ginning } \\
\text { outturn }\end{array}$ & $\begin{array}{c}\text { Seed } \\
\text { index }\end{array}$ \\
\hline Bolls plant $^{-1}$ & $0.07^{\mathrm{ns}}$ & $0.33^{*}$ & & & & & \\
\hline Boll weight $^{\text {Soll }}$ & $-0.16^{\mathrm{ns}}$ & $-0.40^{* *}$ & $-0.27^{\mathrm{ns}}$ & & & & \\
\hline $\begin{array}{c}\text { Seed cotton yield } \\
\text { plant }^{-1}\end{array}$ & $-0.03^{\mathrm{ns}}$ & $0.08^{\mathrm{ns}}$ & $0.79^{* *}$ & $0.35^{*}$ & & & \\
\hline Ginning outturn & $0.05^{\mathrm{ns}}$ & $0.02^{\mathrm{ns}}$ & $0.09^{\mathrm{ns}}$ & $0.20^{\mathrm{ns}}$ & $0.24^{\mathrm{ns}}$ & & \\
\hline Seed index & $0.07^{\mathrm{ns}}$ & $0.24^{\mathrm{ns}}$ & $0.26^{\mathrm{ns}}$ & $-0.34^{*}$ & $0.04^{\mathrm{ns}}$ & $0.14^{\mathrm{ns}}$ & \\
\hline Lint index & $0.02^{\mathrm{ns}}$ & $-0.07^{\mathrm{ns}}$ & $0.08^{\mathrm{ns}}$ & $-0.2^{\mathrm{ns}}$ & $-0.04^{\mathrm{ns}}$ & $0.08^{\mathrm{ns}}$ & $0.02^{\mathrm{ns}}$ \\
\hline Staple length & $0.16^{\mathrm{ns}}$ & $0.001^{\mathrm{ns}}$ & $0.43^{* *}$ & $0.17^{\mathrm{ns}}$ & $0.54^{* *}$ & $0.26^{\mathrm{ns}}$ & $0.25^{\mathrm{ns}}$ \\
\hline Micronaire value & $0.12^{\mathrm{ns}}$ & $-0.05^{\mathrm{ns}}$ & $-0.03^{\mathrm{ns}}$ & $0.34^{*}$ & $0.18^{\mathrm{ns}}$ & $0.02^{\mathrm{ns}}$ & $0.08^{\mathrm{ns}}$ \\
\hline
\end{tabular}

$* *$ = Highly significant at 0.01 probability level, $*=$ Significant at 0.05 probability level, N. S. = Non-significant at 0.05 probability level

\section{Heritability}

Heritability estimates are helpful in deciding the characters to be considered while making selection. The heritability estimates in broad sense, genotypic variance and phenotypic variance derived from variance components for different traits are depicted in (Table 6).

\section{Plant height}

The genetic variance $\sigma^{2} \mathrm{~g}=515.31$ and phenotypic variance $\sigma^{2} \mathrm{p}=567.86$ for the manifestation of plant height brought about high heritability $\mathrm{h}^{2}=90.74 \%$. [15] studied heritability estimates in experiment and stated that this trait was more governed by genes and less by the environment because of the existence of additive gene action.

\section{Sympodial branches plant ${ }^{-1}$}

In case of sympodial branches, genetic variance $\sigma^{2} \mathrm{~g}=37.99$ was almost at par with phenotypic variance $\sigma^{2} \mathrm{p}=38.91$, thus high heritability estimates $h^{2}=97.63 \%$ was achieved. Such heritability estimates were reported in the investigation of [17] in which he demonstrated moderate to high in magnitude for all the traits. Bolls plant $^{-1}$

Bolls plant ${ }^{-1}$ expressed a modest difference in genetic variance $\sigma^{2} \mathrm{~g}=108.32$ and its phenotypic variance $\sigma^{2} \mathrm{p}=118.82$, hence higher heritability estimates $\mathrm{h}^{2}=91.16 \%$ was expected for this character. It was observed by [24], high heritability along with high response to selection was documented in bolls per plant indicating that the additive gene function model in the inheritance of this trait was expressed.

Boll weight

For the character boll weight, the genetic variance $\sigma^{2} \mathrm{~g}=0.12$ and phenotypic variance $\sigma^{2} p=0.13$ were in balance in magnitude that caused heritability $\mathrm{h}^{2}=92.30 \%$. Such high values of heritability for boll weight had also been found by [25] in cotton.

\section{Seed cotton yield plant $^{-1}$}

Seed cotton yield plant $^{-1}$ manifested higher genetic variance $\sigma^{2} \mathrm{~g}=828.67$ which was near to its phenotypic variance $\sigma^{2} p=891.14$, as a consequence, highest heritability estimates $\mathrm{h}^{2}=$ 92.98\% was achieved for seed cotton yield. High broad sense heritability was recorded by [19] for seed cotton yield.

\section{Ginning outturn \%}

For the character ginning outturn, the genetic variance $\sigma^{2} \mathrm{~g}=10.54$ was less than phenotypic variance $\sigma^{2} \mathrm{p}=12.64$, hence heritability estimates $h^{2}=83.38 \%$. [26] found the same results for heritability and informed that it was owing to dominant genes.

\section{Seed index}

For seed index, the genetic variance $\sigma^{2} \mathrm{~g}=4.22$ and phenotypic variance $\sigma^{2} \mathrm{p}=5.65$ and heritability estimates were of $h^{2}=74.69 \%$. [25] checked gene action in his experiment and notified about the dominant genes for the contribution of this attribute. 


\section{Lint index}

For lint index, the genetic variance $\sigma^{2} \mathrm{~g}=1.38$ and phenotypic variance $\sigma^{2} \mathrm{p}=1.19$ thus resulted in moderate heritability estimates $\mathrm{h}^{2}=$ $46.77 \%$. Such moderate results were also defined by [26] and added that it was due to non-additive gene action.

\section{Staple length}

Staple length manifested very smaller difference between genetic variance $\sigma^{2} \mathrm{~g}=3.56$ and phenotypic variance $\sigma^{2} p=5.14$, as a result of $h^{2}=69.26 \%$ heritability was obtained for staple length. [27] investigated this trait and found high heritability estimates but it was regulated by additive genes in place of nonadditive genes.

\section{Micronaire value}

For the character micronaire value, the genetic variance $\sigma^{2} \mathrm{~g}=0.10$ and phenotypic variance $\sigma^{2} \mathrm{p}$ $=0.16$ which resulted moderate heritability estimates $\mathrm{h}^{2}=62.5 \%$. Present results are in consonance with those obtained by [28] who reported high heritability estimates in various quantitative in cotton as well.

Table 6. Heritability estimate in broad sense for various traits in upland cotton

\begin{tabular}{|c|c|c|c|}
\hline Traits & Genotypic variance $\left(\sigma^{2} g\right)$ & Phenotypic variance $\left(\sigma^{2} p\right)$ & Heritability (\%) \\
\hline Plant height & 515.31 & 567.86 & 90.74 \\
\hline Sympodial branches plant $^{-1}$ & 37.99 & 38.91 & 97.63 \\
\hline Bolls plant $^{-1}$ & 108.32 & 118.82 & 91.16 \\
\hline Boll weight & 0.12 & 0.13 & 92.30 \\
\hline Seed cotton yield & 828.67 & 891.14 & 92.98 \\
\hline Ginning out turn & 10.54 & 12.64 & 83.38 \\
\hline Seed index & 4.22 & 5.65 & 74.69 \\
\hline Lint index & 2.54 & 5.43 & 46.77 \\
\hline Staple length & 3.56 & 5.14 & 69.26 \\
\hline Micronaire value & 0.1 & 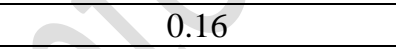 & 62.50 \\
\hline
\end{tabular}

\section{Conclusion}

Present findings clearly demonstrated that cotton production could be increased by increasing sympodial branches plant ${ }^{-1}$ and boll plant $^{-1}$, because seed cotton yield relies upon these traits. Hence, this yield mechanism could be exploited potential material in upcoming breeding programs to mend seed cotton yield. Hence, it was concluded that different quantitative and qualitative attributes would be able to be improved by exploiting promising cultivars of upland cotton.

\section{Authors' contributions}

Conceived and designed the experiments: ZM Kumbhar \& WA Jatoi, Performed the experiments: ZM Kumbhar, WA Jatoi \& AA Gadahi, Analyzed the data: WA Jatoi \& MI Baloch, Contributed materials/ analysis/ tools: KK Menghwar, MS Chang \& M Kachi, Wrote the paper: JK Sootaher.

\section{References}

1. Khan BA, Ahmed NU, Iqbal M, Ihsanullah M, Saleem, Khurshid M \& Kanwal I (2017). Heterosis and Inbreeding Depression in $\mathrm{F}_{2}$ Populations of Upland Cotton (Gossypium hirsutum L.). Agric Sci 1283-1295.

2. Li X, Shahzad K \& Guo L (2019). Using yield quantitative trait locus targeted SSR markers to study the relationship between genetic distance and yield heterosis in upland cotton (Gossypium hirsutum L.). Plant Breed 138(1): 105-13.

3. Farooq J, Anwar M, Riaz M, Farooq A, Mahmood A, Shahid MTH, Rafiq M \& Ilahi F (2014). Correlation and path coefficient analysis of earliness, fiber equality and yield contributing traits in cotton (Gossypium hirsutum L.). The J Anim \& Plant Sci 24(3): 781-790.

4. Ahmad W, Khan NU, Khalil MR, Parveen A, Aimenn U, Saeed M, Samiullah \& Shah SA (2008). Genetic variability and correlation analysis in upland cotton. Sarhad J Agric 24(4): 573-580.

5. Makhdoom KN, Khan U, Batool S, Bibi Z, Farhatullah, Khan S, Mohammad F, Hussain D, Raziuddin, Sajjad M \& Khan $\mathrm{N}$ (2010). Genetic aptitude and correlation studies in G. hirsutum L. Pak J Bot 42(3). 2011-2017.

6. Robert $\mathrm{N}$, Hennequet $\mathrm{C} \&$ Bérard $\mathrm{P}$ (2013). Dry matter and nitrogen accumulation in cotton kernel: genetic variation in rate and duration of grain filling. J Genet \& Breed 55(4): 297-305.

7. Baloch MJ, Kumar C, Jatoi WA \& Rind IH (2014). Phenotypic correlation and regression analysis of yield and fibre traits in upland cotton (Gossypium hirsutum L.). 
Pak J Agri Agrl Engg Vet Sci 30(2): 135146.

8. Tabasum A, Aziz I, Asghar MJ \& Iqbal MZ (2012). Inheritance of seed cotton yield and related traits in cotton $(G$. hirsutum L.). Pak J Bot 44(6): 2027-031.

9. Gomez KA \& Gomez AA (1984). Statistical Procedure for agriculture Research john Wiley and Inc., $2^{\text {nd }}(\mathrm{Ed})$ : New York, U.S.A.

10. Steel RGD \& Torrie JH (1960). Principles and procedures of statistics. McGraw Hill Book Company, New York, Toronto, London, $481 \mathrm{pp}$.

11. Raghavrao D (1983). Statistical technology in agriculture and biological research. Oxford \& IBH Publishing Company. New Dehli, India.

12. Gardener CO (1961). An evaluation of effects of mass selection and seed irradiation with thermal neutrons on yield of corn. Crop Sci 1: 241-245.

13. Khokhar ES, Shakeel A, Maqbool MA, Anwar MW, Tanveer Z \& Irfan MF (2017). Genetic study of cotton (Gossypium hirsutum L.) genotypes for different agronomic, yield and quality traits. Pak J Agric Res 30(4): 363-372.

14. Memon S, Jatoi WA, Veeser NF, Kaleri N, Khanzada S, Kamboh N \& Rajput L (2017). Characterization of elite upland cotton genotypes for earliness and yield traits. J Basic \& Appl Sci 508-513.

15. Nizamani, Baloch FMG, Baloch AW, Buriro M, Nizamani GS, Nizamani MR \& Baloch IA (2017). Genetic distance, heritability and correlation analysis for yield and fibre quality traits in upland cotton genotypes. Pak J Biotechnol 14(1): 29-36.

16. Batool S, Khan NU, Makhdoom K, Bibi Z, Hassan G, Marwat KB, Mohammad FF \& Khan AI (2012). Heritability and genetic potential of upland cotton genotypes for morpho-yield traits. Pak J Bot 42(2): 1057-1064.

17. Raza H, Khan NU, Khan SA, Gul S, Latif A, Hussain I, Khan J, Raza S \& Baloch M (2016). Genetic variability and correlation studies in $\mathrm{F}_{4}$ populations of upland cotton. J Anim \& Plant Sci 26(4): 1048-1055.

18. Muhammad AK, Malik TA, Fatima N, Shakeel A, Karim I, Muhammad A,
Merrium S \& Khanum P (2018). Correlation for economic traits in upland cotton. J Plant Sci 2(1): 118-129.

19. Baloch M, Baloch AW, Baloch MK, Mallano AI, Baloch AM, Baloch NJ \& Abro S (2015). Association and heritability analysis for yield and fiber traits in promising genotypes of cotton (Gossypium hirsutum L.). Sindh Univ Res J 47(2): 303-306.

20. Shibin G, Sahito JH, Rao SH \& Wahocho NA (2016). Association of quantitative traits in upland cotton (Gossypium hirsutum L.). J Appl Environ Biol Sci 6(6): 8-12.

21. Majeedano MS, Ahsan MZ, Soomro AW, Panhwar FA \& Channa AR (2014). Heritability and correlations estimates for some yield traits of Gossypium hirsutum L. American Res J 1(2): 781-790.

22. Khan NU, Hassan G, Marwat KB, Batool S, Makhdoom K, Khan I \& Ahmad W (2012). Genetic variability and heritability in upland cotton. Pak J Bot 41(4): 16951705.

23. Tabasum, Aziz IA, Asghar MJ \& Iqbal MZ (2012). Inheritance of seed cotton yield and related traits in cotton ( $G$. hirsutum L.). Pak J Bot 44(6): 2027-031.

24. Shao D, Wang T, Zhang H, Zhu J \& Tang F (2016). Variation, heritability and association of yield, fiber and morphological traits in a near long staple upland cotton population. Pak J Bot 48(5): 1945-1949.

25. Nawaz B, Sattar S \& Malik TA (2019). Genetic analysis of yield components and fiber quality parameters in upland cotton. Int Multidiscip Res J 9: 13-19.

26. Pandiyan J, Ramalingam A, Pillai MA \& Saravanan S (2019). Genetic parameters of economic and fibre characters in upland cotton (Gossypium hirsutum L.). Int J Curr Microbiol App Sci 8: 2084-2090.

27. Shah SAI, Khan SJ, Ullahand K \& Sayal OU (2018). Genetic diversity in cotton germplasm using multivariate analysis. Sarhad J Agric 34: 130-135.

28. Abbas HG, Mahmood A \& Ali Q (2013). Genetic variability, genetic advance and correlation studies in cotton (G. hirsutum L.). Int J Mol Biol 4: 156-161. 